\title{
9. Fiscal uncertainty: the thankless task of forecasting Asia's fiscal accounts
}

\section{Ugo Panizza ${ }^{1}$}

\section{INTRODUCTION}

This chapter aims to describe and quantify fiscal risk in advanced and developing economies of the world and then examine its main drivers. To quantify fiscal risk, the chapter concentrates on three fiscal outcomes: (1) public debt-to-gross domestic product (GDP) ratio; (2) government budget balance-to-GDP ratio; and (3) primary budget balance-to GDP ratio. ${ }^{2}$

Fiscal risk is measured by comparing the outturn for these variables with the expectations 12 and 24 months before. ${ }^{3}$ The chapter does not focus on the sources of fiscal risk over the long term, such as climate change or unfunded pension liabilities.

Fiscal risk is normally defined as the possibility of deviations of fiscal outcomes from their expected values. As forecasts always contain a margin of error, a better definition of fiscal risk is the possibility of large or systematic deviations of fiscal outcomes from their expected values. There are four main sources of fiscal risk: (1) macroeconomic shocks (mostly GDP growth, exchange rate, inflation, and interest rates); (2) policy shocks (such as policy slippages or changes in government policies); (3) the realization of contingent liabilities; and (4) strategic forecasts (governments that prefer tighter fiscal conditions may use pessimistic forecasts, and the other way around). Some of these sources are easy to measure (for instance, GDP growth); others (such as contingent liabilities and policy slippages) are more difficult to identify and quantify without detailed country studies. In some cases, external factors such as commodity prices, remittances, trading partners growth, and grants from donor countries dictate the shocks; in other cases, the shocks' domestic origins are linked to bad policies or political shocks.

This chapter finds that fiscal risk is substantial especially in the world's emerging and developing economies. The distribution is heavily right skewed for the debt-to-GDP ratio and left skewed for the budget balance-to-GDP ratio, indicating that positive forecast errors for the debt ratio are more common than negative forecast errors, and negative forecast errors for the budget balance are more common than positive forecast errors.

Forecast errors in GDP growth explain about 40 percent of the variance of the forecast error of the debt-to-GDP ratio and budget balance-to-GDP ratio in advanced economies, but errors in growth forecasts explain less than 10 percent of the variance of the forecast error in lowand middle-income countries (a result which also holds for Asian Development Bank (ADB) regional members). A decomposition based on the standard debt-dynamic equation shows that forecast errors of GDP growth, interest rate bill, primary balance, and inflation in advanced 
and developing economies contribute 20-48 percent of the average debt-to-GDP forecast errors. More than 50 percent of the forecast error is associated with what Campos et al. (2006) call "the unexplained part of debt".

Fiscal risk is high especially in bad times, even when these times are expected, because of negative balance sheet effects in developing and emerging market economies and countercyclical policies in advanced economies. While currency depreciations are a large source of fiscal risk in developing and emerging economies, they have no effect on fiscal risk in advanced economies.

While the results of this chapter are based on International Monetary Fund (IMF) forecasts, they are likely to apply also to private sector forecasts as there is no evidence that these forecasts differ in accuracy (Independent Evaluation Office 2014). ${ }^{4}$

The analysis of this chapter focuses on the general government accounts without consolidating the accounts of the central bank. In recent years, nonstandard monetary policies led central banks in advanced economies to accumulate large amounts of government bonds. While consolidating the central bank balance sheet with that of the government would lead to lower "net" debt ratios, the implications of such consolidation for fiscal risk are unclear. The same applies for central banks in emerging market countries that accumulate large international reserves. Such reserve accumulation could counteract the fiscal risk associated with balance sheet effects linked to foreign currency debt because it would reduce the net foreign currency exposure of the consolidated government debt (for a discussion of these issues, see Hausmann and Panizza 2011).

The average values of the fiscal risk indicators of ADB regional members differ from averages for all developing and emerging economies because: (1) forecasts are less optimistic in the average ADB regional member than in other developing and emerging economies; (2) the volatility of forecast errors for the debt-to-GDP ratio in ADB regional members is similar to that for other developing and emerging market economies, but the standard deviation of the forecast error for the budget deficit is higher in ADB regional members; (3) ADB regional members are overrepresented among outliers for which outturns were better than expected. All ADB regional members in this group are Pacific developing member countries).

These findings suggest that fiscal risk in ADB regional members is driven by poor forecasting and data collection capacity by the intrinsic volatility of small economies and commodity exporters. In such a situation, investing in data collection and forecasting ability can give high returns. Countries that are subject to large shocks should instead make greater use of contingent debt instruments such as catastrophe bonds, GDP indexed bonds, or commodity-linked bonds (see Chapter 15 on fiscal insurance in this volume).

This chapter relates to a relatively small body of literature aimed at assessing fiscal risks and developing policies for mitigating these risks. It contributes to the literature by bringing new data to the analysis, studying the correlates of fiscal risk across groups of countries, and conducting a detailed analysis of episodes that have large deviations between fiscal forecasts and outturns.

Schick (1998) is probably the first comprehensive study of the links between fiscal risk and public debt management, and Brixi and Schick (2002) is an early collection of essays on fiscal risk with a particular focus on contingent liabilities.

Campos et al. (2006) do not focus on fiscal risk, but show that exchange rate shocks in the presence of foreign currency debt can play an important role in explaining debt explosions in 
emerging and developing economies (on the drivers of debt explosions, see also Weber (2012) and Jaramillo et al. (2016)). This chapter corroborates the results of Campos et al. (2006) by showing that exchange rate volatility is an important driver of fiscal risk. While Campos et al. (2006) focus on debt explosions, Celasun et al. (2006) study the distribution of fiscal shocks and develop a fan-chart approach to evaluate fiscal risk in emerging market economies.

Cebotari et al. (2009) describe fiscal risk using a methodology similar to that used in this chapter (i.e., by comparing IMF World Economic Outlook (WEO) forecasts with outturns) and also provide an overview of fiscal risk management practices in several advanced and developing economies. ${ }^{5}$ These authors found that macroeconomic shocks (especially exchange rate shocks in the presence of foreign currency debt) and contingent liabilities in the banking system are important drivers of fiscal risk. This chapter updates the data used by Cebotari et al. (2009) and presents a detailed analysis of the correlates of fiscal risk.

Budina and Petrie (2013) provide a detailed discussion of fiscal risks and show that conventional cash-basis government accounting rules amplify fiscal risk because these rules do not allow for an adequate treatment of contingent liabilities. These authors studied the drivers of the increase in the debt and deficit-to-GDP ratio in the aftermath of the global financial crisis. While Budina and Petrie did not conduct a similar analysis for developing and emerging economies, they provide a detailed discussion on how macroeconomic risk should be incorporated in fiscal analysis and on how fiscal risk should be disclosed and mitigated (including a detailed discussion on risk allocation).

IMF (2016) presents a comprehensive analysis of best practices for analyzing and managing fiscal risk. It concludes that countries should aim at collecting "comprehensive, reliable, and timely fiscal data covering all public entities" and "make greater use of probabilistic forecasts methods when setting long-run objectives and medium-term targets for fiscal policy". It also points out that conventional analyses tend to underplay the importance of fiscal risk, and that the balance of risks is skewed toward the downside because (1) forecasts often suffer from an optimist bias; (2) rare and hard-to-predict large negative events are more likely than equally large positive events; and (3) negative shocks are often correlated, with a bunching of contingent liability realizations in crisis periods. The IMF report also developed a methodology that emphasizes tail risks and that is thus suitable for applying the probabilistic approach to debt dynamics in low-income countries.

Part of the analysis of IMF (2016) is based on a novel dataset on the fiscal costs of contingent liabilities assembled by Bova et al. (2019). These authors studied 80 economies (34 advanced economies and 46 developing and emerging economies) over the period 1990-2014 and identified 192 contingent liability episodes. They found that, on average, the economies in their sample had a contingent liability realization with a cost of 6 percent of GDP once every 12 years. The most frequent episodes are associated with financial sector problems; these are also the episodes with the highest fiscal cost. The second most frequent category is disasters triggered by natural hazards, with an average cost of 1.6 percent of GDP. Next are episodes associated with state-owned enterprises, subnational governments, and legal liabilities. Bova et al. (2019) also found that contingent liabilities tend to materialize during periods of low growth and banking crises and that more transparent fiscal accounts and stronger governance indicators are negatively associated with the prevalence and cost of such episodes. 


\section{FISCAL RISK AROUND THE WORLD}

To quantify fiscal risk, we downloaded different vintages of the IMF WEO dataset and compared outturns for the debt-to-GDP ratio, general government balance-to-GDP ratio, and primary balance-to-GDP ratio with their forecasts at time $t-1$ and $t-2$.

We measured the outturn using data from a WEO vintage issued at time $t+2$ (we do not use the latest available dataset to limit problems related to redefinition of variables). ${ }^{6} \mathrm{We}$ adopted the same procedure for GDP growth, inflation, and interest payments.

This section describes the forecast errors for the debt-to-GDP ratio and the budget balance to-GDP ratio (Panizza 2020 reports additional data). It shows separate summary statistics for advanced economies, middle-income economies, and low-income economies as defined by the World Bank. In this chapter, we classify economies into the World Bank's six geographic regions: East Asia and Pacific, Eastern Europe and Central Asia, Latin America and the Caribbean, Middle East and North Africa, South Asia, and sub-Saharan Africa (see Appendix Table 9A.5 for list of economies). We also present separate summary statistics for ADB regional members in the Asia and Pacific subregions: Central and West Asia, East Asia, South Asia, Southeast Asia, and the Pacific.

The main findings of this section are that forecast errors are large, skewed, and downward biased (that is, deficits and debt levels often turn out to be larger than expected). This downward bias tends to be larger in developing economies, but there is substantial variance across developing regions, with the average downward bias being smaller in developing Asia (and in ADB regional members) than in the rest of the developing world. ${ }^{7}$

\subsection{Debt-to-GDP Ratio}

Table 9.1 focuses on the debt-to-GDP ratio. The top panel compares outturns with 1-year ahead forecasts, and the bottom panel compares outturns with 2-year ahead forecasts. In the group of advanced economies (see Appendix Table 9A.5), average outturns for the debt-to-GDP are about 0.4 percent of GDP higher than forecasts at $t-1$ and $t-2$, but the distribution is right skewed with a large dispersion in outcomes. ${ }^{8}$

Fiscal risk is higher in middle-income economies, with outturns for the debt-to-GDP ratio which are on average 3.2 percent of GDP above the forecasts at $t-1$ (5.2 percent at $t-2)$. In this case, the difference is also positive for the median country-year and the distribution is extremely right skewed. ${ }^{9}$ The situation for low-income economies is somewhere in between that of high- and middle-income economies.

Table 9.1 Debt-to-GDP ratio, outturn versus forecasts (\%)

\begin{tabular}{lcccccccc}
\hline Group & Mean & Median & SD & P10 & P25 & P75 & P90 & Skew \\
\hline \multicolumn{2}{l}{ Outturn $-E_{t-1}$ (all available years) } & & & & & & & \\
\hline AE & 0.36 & -0.36 & 9.48 & -7.87 & -4.00 & 3.95 & 10.61 & 0.42 \\
MIC & 3.16 & 1.89 & 8.28 & -4.18 & -1.71 & 5.91 & 15.11 & 1.02 \\
LIC & 0.85 & 0.32 & 13.32 & -11.59 & -4.92 & 5.68 & 13.02 & 1.07 \\
EAP & 0.48 & 0.00 & 8.00 & -6.90 & -3.06 & 3.66 & 7.69 & 0.48 \\
ECA & 0.50 & -0.38 & 9.53 & -8.34 & -4.15 & 4.17 & 10.50 & 1.04
\end{tabular}




\begin{tabular}{lccccccrr}
\hline Group & Mean & Median & SD & P10 & P25 & P75 & P90 & Skew \\
\hline Outturn - E $t_{t-1}$ (all available years) & & & & & & & \\
\hline LAC & 1.25 & 1.10 & 11.97 & -10.61 & -3.68 & 6.08 & 12.52 & 0.17 \\
MNA & 3.25 & 2.06 & 10.54 & -9.32 & -2.52 & 8.37 & 18.69 & 0.41 \\
SA & -1.23 & 0.84 & 13.77 & -17.15 & -1.34 & 4.07 & 9.63 & -1.66 \\
SSA & 4.09 & 2.55 & 15.23 & -12.42 & -3.21 & 10.21 & 21.39 & 0.91 \\
ADB & -0.23 & -0.02 & 9.67 & -8.04 & -3.33 & 3.46 & 7.78 & -0.81 \\
\hline Outturn $-E_{t-2}$ (all available years) & & & & & & \\
\hline AE & 0.4 & -0.3 & 11.3 & -12.1 & -4.9 & 5.7 & 14.2 & 0.13 \\
MIC & 5.2 & 2.8 & 10.8 & -5.4 & -0.8 & 9.8 & 19.3 & 0.82 \\
LIC & 2.0 & 1.5 & 15.8 & -12.7 & -4.7 & 8.1 & 17.7 & 0.21 \\
EAP & 1.0 & 0.5 & 8.9 & -8.1 & -3.3 & 5.7 & 10.0 & -0.02 \\
ECA & 1.2 & 0.2 & 11.9 & -12.0 & -5.0 & 6.6 & 15.1 & 0.65 \\
LAC & 1.9 & 1.9 & 14.6 & -12.4 & -4.0 & 8.2 & 17.6 & -0.43 \\
MNA & 6.4 & 3.9 & 14.0 & -8.9 & -2.4 & 14.8 & 24.9 & 0.46 \\
SA & -1.8 & 1.7 & 17.9 & -18.7 & -3.0 & 6.1 & 11.1 & -1.84 \\
SSA & 6.5 & 5.0 & 17.6 & -11.3 & -2.8 & 14.7 & 27.9 & 0.30 \\
ADB & -0.03 & 0.46 & 11.95 & -10.74 & -4.56 & 5.38 & 11.10 & -1.42 \\
\hline
\end{tabular}

Notes:

$\mathrm{ADB}=$ Asian Development Bank; AE = advanced economy; EAP = East Asia and Pacific; ECA = Eastern Europe and Central Asia; GDP = gross domestic product; LAC = Latin America and the Caribbean; LIC = low-income country; MNA = Middle East and North Africa; SA = South Asia; SSA = sub-Saharan Africa; WEO = World Economic Outlook.

See Appendix Table 9A.5 for a list of economies in various groups.

Source: Author's calculations based on different vintages of WEO data.

Within the group of developing economies in the World Bank regions, the average difference between outturns and forecasts is particularly large in sub-Saharan Africa and in the Middle East and North Africa, while East Asia and Pacific and Eastern Europe and Central Asia have values similar to those of the advanced economies (especially for forecasts at $t-1$ ). South Asia is the only region for which the average country has an outturn for the debt-to-GDP ratio which is lower than the forecast and for which the distribution is left skewed.

The data for ADB regional members are somewhere in between those of economies in the World Bank's East Asia and Pacific and South Asia. The average forecast error is negative, the median error is zero, and the distribution is right skewed. While these values suggest that downside fiscal risk is, on average, smaller within ADB regional members, the within-group variance tends to be large, with positive forecast errors in the World Bank's East Asia subregion and negative forecast errors in South Asia (Appendix Table 9A.1).

Focusing on 2020 data, we find very large differences between the WEO forecasts issued in October 2019 and in June 2020 (see Figure 1 in Panizza 2020). Differences are particularly large for advanced economies (17 percent of GDP on average) and slightly smaller for middleand low-income economies (10 percent of GDP and 7 percent of GDP, respectively).

Among groups of developing economies (Appendix Table 9A.5), the average difference between outturns and forecasts is higher in Latin America, Eastern Europe and Central Asia, and the Middle East and North Africa, and much lower in East Asia and Pacific. The forecast 
errors are also positive and large for all ADB regional members, and especially large for South Asia.

\subsection{Budget Balance}

Focusing on the budget balance (Table 9.2), we find that advanced economies had budget deficits which, on average, were 0.3 percent of GDP larger than expected one year before. However, the median country had a smaller deficit (or a larger surplus) than expected and the distribution of outcomes is only slightly left skewed. ${ }^{10}$

In the case of middle-income economies, the average outturn for the budget balance is nearly 1 percent of GDP below the 1-year ahead forecast (1.4 percent of GDP for 2-year ahead expectations). The distribution is heavily left skewed, with the value at the 10th percentile almost twice as large (in absolute value) as the value at the 90th percentile. As in the case of the debt-to-GDP ratio, the behavior of low-income countries is somewhere in between that for middle- and high-income economies.

Within the group of developing economies in the World Bank regions, we find that the average outturn in East Asia and Pacific was 0.75 percent of GDP above the expected 1-year ahead forecast and almost identical to two years ahead. In this region, we also find a right skewed distribution of the forecast error. However, there are large differences within the East Asia and Pacific region, with the deviation between outturns and 1-year ahead expectations ranging from -4.4 percent of GDP for the country-year at the 10th percentile of the distribution and 5 percent of GDP for the country-year at the 90th percentile of the distribution. In the Middle East and North Africa, on the other hand, deficits were on average much larger than expected, with a difference between outturn and 1-year ahead forecasts of 1.2 percent of GDP (1.8 percent of GDP for 2-year ahead expectations). There is also a large dispersion of outcomes in this case.

Table 9.2 Budget balance-to-GDP ratio, outturn versus forecasts (\%)

\begin{tabular}{lcccccccc}
\hline Group & Mean & Median & SD & P10 & P25 & P75 & P90 & Skew \\
\hline \multicolumn{2}{l}{ Outturn $-\mathrm{E}_{t-1}$ (all available years) } & & & & & & & \\
\hline AE & -0.28 & 0.22 & 3.21 & -3.39 & -1.16 & 1.31 & 2.51 & -1.39 \\
MIC & -0.90 & -0.43 & 5.33 & -5.58 & -2.63 & 1.12 & 2.99 & -1.16 \\
LIC & -0.58 & -0.21 & 4.90 & -5.47 & -2.20 & 1.41 & 3.82 & -1.57 \\
EAP & 0.75 & 0.20 & 7.68 & -4.40 & -1.59 & 1.86 & 5.06 & 2.41 \\
ECA & -0.33 & 0.24 & 3.36 & -4.53 & -1.50 & 1.44 & 2.77 & -0.99 \\
LAC & -0.42 & -0.30 & 4.59 & -4.79 & -2.10 & 0.98 & 3.03 & 3.29 \\
MNA & -1.22 & -0.72 & 8.38 & -9.40 & -4.31 & 1.88 & 6.11 & -0.84 \\
SA & -0.32 & -0.08 & 4.30 & -3.97 & -1.77 & 0.98 & 3.54 & -0.21 \\
SSA & -0.97 & -0.52 & 5.57 & -6.78 & -3.12 & 1.42 & 4.73 & -1.06 \\
ADB & 1.0 & 0.0 & 7.6 & -4.6 & -2.0 & 1.9 & 5.6 & 3.17 \\
\hline
\end{tabular}




\begin{tabular}{lcccccccc}
\hline Group & Mean & Median & SD & P10 & P25 & P75 & P90 & Skew \\
\hline \multicolumn{2}{l}{ Outturn - E (all available years) (arl } & & & & & & & \\
\hline AE & -0.57 & 0.07 & 3.77 & -5.24 & -1.95 & 1.42 & 2.78 & -1.06 \\
MIC & -1.39 & -0.76 & 6.30 & -6.78 & -3.13 & 0.79 & 3.24 & -1.17 \\
LIC & -0.99 & -0.77 & 6.45 & -6.23 & -2.99 & 1.30 & 4.19 & -1.15 \\
EAP & -0.08 & -0.05 & 9.77 & -5.43 & -2.14 & 1.90 & 4.89 & -0.31 \\
ECA & -0.63 & 0.01 & 3.73 & -5.52 & -2.14 & 1.42 & 2.97 & -1.16 \\
LAC & -0.57 & -0.87 & 6.15 & -5.85 & -2.82 & 1.00 & 3.63 & 5.52 \\
MNA & -1.83 & -0.97 & 9.74 & -12.25 & -5.28 & 1.89 & 7.75 & -0.75 \\
SA & -0.75 & -0.51 & 4.47 & -5.59 & -2.77 & 1.06 & 3.64 & -0.15 \\
SSA & -1.42 & -1.13 & 6.46 & -7.38 & -3.76 & 1.03 & 4.92 & -1.60 \\
ADB & 0.6 & -0.2 & 8.6 & -5.3 & -2.4 & 2.0 & 5.8 & 1.62 \\
\hline
\end{tabular}

Notes:

$\mathrm{ADB}=$ Asian Development Bank; $\mathrm{AE}=$ advanced economy EAP $=$ East Asia and the Pacific $; \mathrm{ECA}=$ Eastern Europe and Central Asia; GDP = gross domestic product; LAC = Latin America and the Caribbean; LIC = low-income country; MNA = Middle East and North Africa; SA = South Asia; SSA = sub-Saharan Africa; WEO = World Economic Outlook.

See Appendix Table 9A.5 for a list of economies in various groups.

Source: Author's calculations based on different vintages of WEO data.

The average for ADB regional members has a fiscal outturn which is a 1 percentage point of GDP above what was expected at $t-1$, and the median country has a forecast error which is close to zero. The strong performance of ADB regional members, however, is due to the behavior of a few outliers in the Pacific subregion (Appendix Table 9A.2). There are large positive values in some Pacific developing member countries (Kiribati, the Federated States of Micronesia, Nauru, Solomon Islands, and Tuvalu). On the other hand, the forecast errors are negative in Central and West Asia and in East Asia, and they are close to zero in South Asia and Southeast Asia. There are large negative values (below 1 percent of GDP) in India, Kazakhstan, the Kyrgyz Republic, Mongolia, Pakistan, Papua New Guinea, Samoa, and Sri Lanka. Commodity-producing countries like Azerbaijan and Kazakhstan also have large swings in the difference between the expected and actual budget balances.

The overall pattern for the primary budget balance (Table 3 in Panizza 2020) is similar to that of the overall balance, but with larger negative values for advanced and low-income countries, indicating that in some of these countries, forecasts overstated real interest rate expenditures.

\section{THE ROLE OF FORECAST ERRORS IN DEBT-DYNAMIC VARIABLES}

The standard debt-dynamic equation expresses the change in the debt-to-GDP ratio as a function of the primary deficit, interest rates, inflation, and real GDP growth. This section studies how forecast errors in the debt-dynamic variables contribute to errors in debt-to-GDP ratio forecasts.

Before considering all these variables together, we first studied the role of forecast errors in GDP growth, because growth is a key component of fiscal risk. 


\subsection{Fiscal Risk and GDP Growth Forecast Errors}

To study how forecast errors on GDP growth at time $t-1$ and $t-2$ affect fiscal risk, we first estimate the following regression:

$$
d_{t, c}-E_{t-i}\left(d_{t, c}\right)=\alpha+\beta\left(g_{t, c}-E_{t-i}\left(g_{t, c}\right)\right)+\varepsilon_{t, c}
$$

Where $d_{t, c}$ and $g_{t, c}$ are the debt-to-GDP ratio and real GDP growth at time $t$ in country $c$, and $E_{t-i}$ denotes expectations taken at time $t-i$.

The first column of Table 9.3 shows that when growth of advanced economies is 1 percentage point lower than expected, the debt-to-GDP ratio grows 1.7 percentage points of GDP more than expected. Errors in growth forecasts explain 40 percent of the variance in errors of public debt-to-GDP forecasts. The second column of Table 9.3 estimates a model similar to that of column 1, but which also allows for country-specific fixed effects (i.e., it controls for the fact that certain economies may make systematic errors in their debt-to-GDP ratio forecasts). Controlling for fixed effects does not alter the correlation between errors in growth forecasts and errors in debt-to-GDP forecasts, and the fixed effects only explain 7 percent of the variance of debt-to-GDP forecast errors.

Table 9.3 Debt-to-GDP ratio and GDP growth, outturn versus forecasts (\%)

\begin{tabular}{|c|c|c|c|c|c|c|c|c|}
\hline & (1) & (2) & (3) & (4) & (5) & (6) & (7) & (8) \\
\hline & $\mathbf{A E}$ & $\mathbf{A E}$ & MIC & MIC & LIC & LIC & ADB & ADB \\
\hline \multicolumn{9}{|l|}{ Outturn $-E_{t-1}$} \\
\hline \multirow[t]{2}{*}{ GR-E(GR) } & $-1.658 * * *$ & $-1.648 * * *$ & $-0.421 * * *$ & $-0.720 * * *$ & $-1.067 * * *$ & $-0.904 * * *$ & $-0.82 * * *$ & $-1.02 * * *$ \\
\hline & $(-16.27)$ & $(-16.09)$ & $(-5.85)$ & $(-6.83)$ & $(-6.31)$ & $(-4.95)$ & $(-4.94)$ & $(-6.39)$ \\
\hline \multirow[t]{2}{*}{ Const. } & $-0.011^{* * *}$ & $-0.011^{* * *}$ & $0.024 * * *$ & $0.018 * * *$ & -0.006 & -0.004 & $-0.01 *$ & $-0.01 * *$ \\
\hline & $(-2.932)$ & $(-2.976)$ & (5.295) & (4.046) & $(-0.832)$ & $(-0.561)$ & $(-1.77)$ & $(-2.32)$ \\
\hline N. Obs. & 407 & 407 & 347 & 347 & 341 & 341 & 232 & 232 \\
\hline $\mathrm{R}^{2}$ & 0.3953 & 0.4723 & 0.0904 & 0.2994 & 0.1051 & 0.3321 & 0.0963 & 0.3425 \\
\hline Country FE & $\mathrm{NO}$ & YES & NO & YES & $\mathrm{NO}$ & YES & NO & YES \\
\hline
\end{tabular}

Notes:

$* * * \mathrm{p}<0.01, * * \mathrm{p}<0.05, * \mathrm{p}<0.1$.

$\mathrm{ADB}=$ Asian Development Bank; $\mathrm{AE}=$ advanced economy; GDP = gross domestic product; LIC $=$ low-income country; $\mathrm{MIC}=$ middle-income country; WEO = World Economic Outlook.

t-statistics in parentheses.

See Appendix Table 9A.5 for a list of economies in various groups.

Source: Author's calculations based on different vintages of WEO data.

In middle-income countries there is a much smaller correlation between errors in growth forecasts and errors in debt-to-GDP forecasts. In this sample of countries, when growth is 1 percentage point lower than expected, the debt-to-GDP ratio increases by 0.4 percentage point of GDP more than expected, and errors in growth forecasts explain less than 10 percent of the variance of debt-to-GDP forecast errors (column 3). Controlling for country-fixed effects increases the correlation between errors in growth forecasts and errors in debt-to-GDP from 0.4 to 0.7 and contributes to explaining 20 percent of the variance debt-to-GDP forecast errors 
(column 4). In low-income economies (columns 5 and 6), a 1 percentage point forecast error in GDP growth is associated with a 1 percentage point error in the debt-to-GDP ratio. Also, in this case, country-specific effects explain most of the variance of the forecast errors. The last two columns show that ADB regional members are similar to the average middle-income country in terms of the share of variance explained by growth forecast errors but close to low-income countries in terms of point estimates. ${ }^{11}$

Looking at World Bank regional subgroups, we find that forecast errors in GDP growth are an important driver of forecast errors for the debt-to-GDP ratio in Eastern Europe and Central Asia (the correlation between the two errors and the fit of the regression are similar to those of advanced economies), and that forecast errors in GDP growth are not a key driver of forecast errors in debt-to-GDP in East Asia and Pacific, Middle East and North Africa, and sub-Saharan Africa.

There are also large differences across ADB regional members in Asia and the Pacific. GDP growth forecast errors are important in South Asia, while they seem to matter less in East Asia and the Pacific. This is especially the case for 2-year forecasts. In this case, GDP growth forecast errors are not significantly correlated with debt-to-GDP forecasts in Central and West Asia, East Asia, and the Pacific.

Taken together, these results suggest that errors in growth forecasts play an important role (albeit not the most important) in explaining fiscal risk in advanced economies, but that country-specific idiosyncratic factors are more important drivers of fiscal risk in middle- and low-income economies.

\subsection{Fiscal Risk and Debt Dynamics}

It is possible to use the standard debt-dynamic equation to explore the relative contributions of forecast errors for the primary balance, interest rates, inflation, and GDP growth to forecast errors in the debt-to-GDP ratio.

Standard debt-dynamic accounting allows the debt-to-GDP ratio to be expressed as a function of its lagged value minus the primary balance over GDP, plus the interest rate bill, minus nominal GDP growth (given by real GDP growth plus inflation) multiplied by the lagged debt-to-GDP ratio, plus the stock flow reconciliation. ${ }^{12}$ Formally:

$$
d_{t}=d_{t-1}(1+i-\pi-g)-p b+s f
$$

Where $d$ is the debt-to-GDP ratio, $i$ the interest rate, $g$ real GDP growth, A the inflation rate, $p b$ the primary balance-to-GDP ratio, and $s f$ the stock-flow reconciliation.

Taking expectations at time $t-1$ yields:

$$
E_{t-1} d_{t}=d_{t-1}\left(1+E_{t-1} i-E_{t-1} \pi-E_{t-1} g\right)-E_{t-1} p b+E_{t-1} s f
$$


Subtracting (9.3) from (9.2) and dividing by $d_{t-1}$, we obtain:

$$
\begin{aligned}
& \frac{d_{t}-E_{t-1} d_{t}}{d_{t-1}}=\left(i-E_{t-1} i\right)-\left(\pi-E_{t-1} \pi\right) \\
& +\left(g-E_{t-1} g\right)-\frac{p b_{t}-E_{t-1} p b_{t}}{d_{t-1}}+\frac{s f_{t}-E_{t-1} s f_{t}}{d_{t-1}}
\end{aligned}
$$

As the only component of equation (9.4) which is not observable is the stock-flow reconciliation, this variable is obtained as a residual.

The four components in the right-hand side of equation (9.4) describe the relative contribution of measurement errors in the four elements of the debt-dynamic equation to forecast errors in the debt-to-GDP ratio as a proportion of the lagged debt-to-GDP ratio.

Table 9.4 shows that forecast errors in the primary balance of advanced economies account for approximately 19 percent of the forecast error in the debt-to-GDP ratio, growth shocks account for 8 percent, interest rate shocks for 3 percent, and inflation shocks for less than 1 percent. Much of the prediction error (72 percent) is not associated with the standard debt-dynamic components (a fact Campos et al. 2006 already show in a different setup), but with the residual stock-flow reconciliation. The second row of Table 9.4 shows a large variation in these shares.

Table 9.4 Debt-to-GDP ratio and GDP growth, decomposition of outturn versus

\begin{tabular}{|c|c|c|c|c|c|}
\hline & $p b$ & int & inf & $g r$ & $\varepsilon$ \\
\hline \multicolumn{6}{|c|}{ Outturn - $\mathrm{E}_{t-1}$} \\
\hline $\mathrm{AE} \mu$ & 18.6 & 3.1 & -0.3 & 7.9 & 71.9 \\
\hline $\mathrm{AE} \sigma$ & 56.7 & 14.4 & 26.1 & 25.6 & 81.2 \\
\hline $\operatorname{MIC} \mu$ & 21.7 & 2.8 & 1.8 & 7.8 & 76.2 \\
\hline $\mathrm{MIC} \sigma$ & 77.3 & 14.9 & 28.8 & 25.6 & 96.7 \\
\hline $\operatorname{LIC} \mu$ & 12.9 & 1.8 & 0.7 & 4.1 & 82.9 \\
\hline $\mathrm{LIC} \sigma$ & 63.7 & 11.2 & 26.9 & 21.5 & 75.8 \\
\hline $\mathrm{EAP} \mu$ & 20.7 & 2.6 & 1.3 & 3.8 & 75.4 \\
\hline $\mathrm{EAP} \sigma$ & 78.5 & 12.4 & 24.4 & 22.7 & 100.1 \\
\hline $\mathrm{ECA} \mu$ & 22.8 & 3.0 & -0.3 & 7.9 & 68.6 \\
\hline $\mathrm{ECA} \sigma$ & 60.0 & 13.4 & 27.3 & 24.1 & 81.8 \\
\hline $\mathrm{LAC} \mu$ & 17.5 & 1.2 & -1.4 & 3.4 & 79.9 \\
\hline $\mathrm{LAC} \sigma$ & 63.0 & 14.4 & 31.2 & 27.9 & 82.3 \\
\hline MNA $\mu$ & 23.7 & 2.5 & -0.7 & 5.8 & 77.0 \\
\hline MNA $\sigma$ & 74.8 & 14.7 & 24.8 & 21.7 & 101.8 \\
\hline $\mathrm{SAS} \mu$ & 31.7 & 5.3 & 6.1 & 12.8 & 51.9 \\
\hline $\mathrm{SAS} \sigma$ & 76.6 & 14.3 & 28.0 & 30.4 & 111.2 \\
\hline
\end{tabular}
forecasts (\%) 


\begin{tabular}{lrrrrr}
\hline & $\boldsymbol{p b}$ & $\boldsymbol{i n t}$ & $\boldsymbol{i n f}$ & $\boldsymbol{g r}$ & $\boldsymbol{\varepsilon}$ \\
\hline Outturn $-\mathrm{E}_{t-1}$ & & & & & \\
\hline $\mathrm{SSA} \mu$ & 10.4 & 2.2 & 0.2 & 3.2 & 87.8 \\
$\mathrm{SSA} \sigma$ & 55.5 & 9.2 & 26.2 & 21.1 & 71.6 \\
$\mathrm{ADB} \mu$ & 23.3 & 2.7 & 3.4 & 7.1 & 59.8 \\
$\mathrm{ADB} \sigma$ & 126.5 & 12.7 & 30.6 & 23.7 & 137.6 \\
\hline
\end{tabular}

Notes:

$\mu=$ mean; $\sigma=$ standard deviation; $\mathrm{ADB}=$ Asian Development Bank; AE = advanced economy; $\mathrm{EAP}=$ East Asia and

Pacific; ECA = Eastern Europe and Central Asia; GDP = gross domestic product; LAC = Latin America and the Caribbean; MNA = Middle East and North Africa; SA = South Asia; SSA = sub-Saharan Africa; WEO = World Economic Outlook.

See Appendix Table 9A.5 for a list of economies in various groups.

Source: Author's calculations based on different vintages of WEO data.

The variation of the shares in middle-income economies is similar to advanced economies, but inflation shocks are more important contributors, and in low-income economies, primary balance and growth forecast errors are less important contributors to the debt-to-GDP ratio forecast error. More than 80 percent of this forecast error is associated with the unexplained residual.

Within the World Bank groups of developing economies, primary balance shocks are especially important in South Asia and in the Middle East and North Africa regions. South Asia also has the smallest unexplained component (which, however, still accounts for 50 percent of the debt-to-GDP forecast error) and the region where all types of shocks play an important role in explaining debt-to-GDP forecast errors.

In ADB regional members, on average nearly one-quarter of the forecast error in debt-to-GDP is explained by forecast errors in the primary balance and about 10 percent by forecast errors in nominal GDP growth ( 3 percent inflation and 7 percent real growth); and the unexplained residual is associated with 60 percent of the forecast errors (Table 9A.3). There are large variations among ADB regional members (Table 9A.4). Errors in the primary balance are particularly important in Central and West Asia (where they account for 60 percent of the forecast error in the debt-to-GDP ratio, and the unexplained part "only" accounts for 24 percent of the forecast error), but also in Southeast Asia and the Pacific.

The case of East Asia is interesting because this subregion is characterized by large forecast errors in the primary balance, but these errors go in the opposite direction with respect to other economies. East Asian economies have, on average, outturns for the budget deficit which are smaller than predicted at time $t-1$. There are also negative contributions from interest rates and inflation. The counterpart of these negative contributions is a large share for the unexplained part which, in these countries, amounts to 200 percent. In East Asia, fiscal forecasts are too conservative!

\subsection{Budget Balance and Growth Forecast Errors}

As GDP growth and the budget balance (especially the primary balance) are both important drivers of forecast errors in the debt-to-GDP ratio, it is interesting to explore the correlation between forecast errors in these two variables. 
Table 9.5 reports the results of an exercise similar to that of Table 9.3, but focusing on forecast errors in the budget balance over GDP instead of the debt-to-GDP ratio. Columns 1 and 2 show that in advanced economies a 1 percent error in growth forecast is associated with a 0.7 percentage point error in budget balance forecast. The regressions also show that in advanced economies, errors in growth forecast explain more than 40 percent of the variance budget balance forecast errors, and country-fixed effects explain less than 5 percent of this variance.

Table 9.5 Budget balance-to-GDP ratio and GDP growth, outturn versus forecasts (\%)

\begin{tabular}{|c|c|c|c|c|c|c|c|c|}
\hline & (1) & (2) & (3) & (4) & (5) & (6) & (7) & (8) \\
\hline & $\mathbf{A E}$ & $\mathbf{A E}$ & MIC & MIC & LIC & LIC & ADB & ADB \\
\hline \multicolumn{9}{|l|}{ Outturn $-E_{t-1}$} \\
\hline \multirow[t]{2}{*}{ GR-E(GR) } & $0.698 * * *$ & $0.713 * * *$ & $0.157 * * *$ & $0.162 * * *$ & $0.208 * * *$ & $0.190 * * *$ & $0.32 * * *$ & $0.26 * * *$ \\
\hline & (25.07) & $(25.48)$ & $(4.96)$ & $(4.90)$ & $(5.56)$ & $(5.12)$ & $(4.11)$ & $(3.87)$ \\
\hline \multirow[t]{2}{*}{ Const. } & $0.0014 *$ & $0.002 *$ & $-0.007 * * *$ & $-0.006^{* * *}$ & -0.003 & $-0.003^{*}$ & $0.01 * * *$ & $0.01 * * *$ \\
\hline & (1.69) & $(1.82)$ & $(-3.08)$ & $(-3.09)$ & $(-1.44)$ & $(-1.69)$ & $(3.62)$ & $(4.16)$ \\
\hline N. Obs. & 842 & 842 & 647 & 647 & 641 & 641 & 473 & 473 \\
\hline $\mathrm{R}^{2}$ & 0.428 & 0.47 & 0.036 & 0.134 & 0.046 & 0.227 & 0.0346 & 0.3724 \\
\hline Country FE & NO & YES & NO & YES & NO & YES & NO & YES \\
\hline
\end{tabular}

Notes:

$* * * \mathrm{p}<0.01, * * \mathrm{p}<0.05, * \mathrm{p}<0.1$.

$\mathrm{ADB}=$ Asian Development Bank; AE = advanced economy; GDP = gross domestic product; LIC = low-income country; MIC = middle-income country; WEO = World Economic Outlook.

$\mathrm{t}$-statistics in parentheses.

See Appendix Table 9A.5 for a list of economies in various groups.

Source: Author's calculations based on different vintages of WEO data.

The relationship between forecast errors in GDP growth and forecast errors in the budget balance is much weaker in middle-income economies. In this case, a 1 percentage point error in growth forecasts is associated with a 15-20 basis points error in budget balance forecasts (Table 9.5, columns 3-6). In middle-income economies, growth forecast errors explain less than 5 percent of the variance in budget balance forecast errors. The last two columns focus on ADB regional members. The share of variance explained by growth forecast errors is similar to that of middle-income economies, but the point estimates are larger than those in the full sample of middle-income economies, and they remain significant for 2-year ahead forecasts. ${ }^{13}$

As in the case of debt-to GDP ratio, we find that GDP growth shocks are an important factor in predicting forecast errors in the budget balance (and the primary budget balance) in Eastern Europe and Central Asia and that they are less important in South Asia (where the correlation is not even statistically significant), sub-Saharan Africa, and East Asia.

The main takeaway of this subsection is that forecast errors in GDP growth are important drivers of fiscal risk. In the average middle-income economy, they contribute about 8 percent to the debt-to-GDP ratio forecast error (Table 9.4). However, this is not their only contribution to fiscal risks as shocks to GDP growth are also strongly correlated with forecast errors in the primary balance which, in turn, explain 22 percent of the forecast errors in the debt-to-GDP ratio. 


\section{THE CORRELATES OF FISCAL RISK}

This section studies which variables are correlated with fiscal risk. As before, we start with forecast errors in the debt-to-GDP ratio and then move to forecast errors in the budget balance. As Table 9.4 showed that forecast errors in GDP growth are a key driver of forecast errors in public debt-to-GDP, we start by unpacking equation (1) and estimate the following model:

$$
d_{t, c}-E_{t-i}\left(d_{t, c}\right)=a_{c}+\beta g_{t, c}+\gamma E_{t-i}\left(g_{t, c}\right)+\varepsilon_{t, c}
$$

Note that equation (9.1) is equivalent to estimating equation (9.5) together with the restriction that $\beta=-\gamma$.

The first four columns of Table 9.6 show that $\beta$ is approximately equal to $-\gamma$ in developing and emerging economies but that in advance economies $\beta=-2 \gamma$, and that $\gamma$ is not even statistically significant ( $\gamma$ is only marginally significant in ADB regional members).

The point estimates suggest that in advanced economies, a 1 percentage point forecast error for GDP growth is associated with an 80 basis point increase in the debt-to-GDP ratio over and above what was expected, but that another 80 basis point surprise in the debt-to-GDP ratio is associated to the GDP growth outcome itself, irrespective to what expected growth was. The results indicate a systematic underestimation of countercyclical fiscal policy in debt-to-GDP forecasts in advanced economies, but not in developing and emerging economies. This result is likely to be due to the fact that countercyclical fiscal policies are not in place in the average developing and emerging economy.

Table 9.6 Debt surprises and GDP growth

\begin{tabular}{lcccccccc}
\hline & $\mathbf{( 1 )}$ & $\mathbf{( 2 )}$ & $\mathbf{( 3 )}$ & $\mathbf{( 4 )}$ & $\mathbf{( 5 )}$ & $\mathbf{( 6 )}$ & $\mathbf{( 7 )}$ & $\mathbf{( 8 )}$ \\
\hline GR & $-0.957^{* * *}$ & $-1.694^{* * *}$ & $-0.831^{* * *}$ & $-1.028^{* * *}$ & & & & \\
& $(0.0997)$ & $(0.210)$ & $(0.100)$ & $(4.77)$ & & & & \\
E(GR) & $0.746^{* * *}$ & 0.865 & $0.694^{* * *}$ & $0.992^{*}$ & $0.629 * * *$ & 0.765 & $0.561^{* * *}$ & $0.951^{*}$ \\
& $(0.145)$ & $(0.879)$ & $(0.141)$ & $(1.982)$ & $(0.177)$ & $(0.913)$ & $(0.183)$ & $(1.89)$ \\
GRxGT & & & & $-0.549^{* *}$ & $-1.514^{* * *}$ & -0.378 & -0.568 \\
& & & & $(0.235)$ & $(0.299)$ & $(0.269)$ & $(1.18)$ \\
GRxBT & & & & $-0.933^{* * *}$ & $-1.800^{* * *}$ & $-0.791^{* * *}$ & $-1.10^{* * *}$ \\
& & & & $(0.132)$ & $(0.267)$ & $(0.132)$ & $(3.71)$ \\
BT & & & & & $0.027 * *$ & -0.001 & $0.033^{* *}$ & 0.027 \\
& & & & & $(0.011)$ & $(0.014)$ & $(0.015)$ & $(0.86)$ \\
N. Obs & 1,697 & 317 & 1,380 & 232 & 1,697 & 317 & 1,380 & 232 \\
N. Cy & 190 & 26 & 164 & 31 & 190 & 26 & 164 & 31 \\
Cy FE & Yes & Yes & Yes & Yes & Yes & Yes & Yes & No \\
Sample & All & AE & DEV\&EM & ADB & All & AE & DEV\&EM & ADB \\
\hline
\end{tabular}

Notes:

$* * * \mathrm{p}<0.01, * * \mathrm{p}<0.05, * \mathrm{p}<0.1$.

$\mathrm{ADB}=$ Asian Development Bank; $\mathrm{AE}=$ advanced economy; DEV\&EM = developing and emerging; GDP = gross domestic product; WEO = World Economic Outlook.

Robust standard errors in parentheses.

See Appendix Table 9A.5 for a list of economies in various groups.

Source: Author's elaborations based on different vintages of WEO data. 
As a next step, we created "bad times" and "good times" dummy variables (the bad times dummy variable takes value 1 when GDP growth is below the country-specific median growth, the good times dummy is the opposite), and then we augmented equation (9.5) with this dummy and the interaction between each of the two dummies and realized GDP growth.

Column 6 shows that, conditional on GDP growth, in advanced economies there are no differences in debt-to-GDP forecast errors between good and bad times (the coefficient for the dummy is not statistically significant and with a point estimate close to zero), and the correlation between GDP growth and debt-to-GDP forecast errors tends to be higher during bad times. However, the difference in this correlation between good and bad times is small.

In developing and emerging economies, we also find that the correlation between GDP growth and debt-to-GDP forecast errors is higher during bad times (twice as high as in good times, column 7). However, controlling for GDP growth, the debt-to-GDP ratio forecast error increases by 3 percentage points during bad times. The results for ADB regional members are similar to those of developing and emerging economies (column 8). The Independent Evaluation Office (2014) found significant over prediction of GDP growth during recessions and crisis times; Table 9.8 shows that these biases extend to fiscal forecasts even after controlling for the bias in GDP forecasts. ${ }^{14}$

Table 9.7 studies the roles of exchange rate and inflation. It shows that exchange rate depreciations $(D X R<0)$ play no role in advanced economies (column 2$)$, but they are an important determinant of fiscal risk in developing economies. The coefficient is particularly large in ADB regional members (columns 3 and 4). This result is likely because developing and emerging market economies tend to have part of their public debt denominated in foreign currency (Eichengreen et al. 2005; and Panizza and Taddei 2020). The point estimates of columns 3 and 4 indicate that a 10 percent currency depreciation is associated with a 2.5 percentage point unexpected increase in the debt-to-GDP ratio of developing and emerging economies and 4 percentage points in ADB regional members.

Inflation is associated with an unexpected increase in the debt-to-GDP ratio in advanced economies (column 6), but has no effect on public debt surprises in developing and emerging economies (columns 7 and 8).

Table 9.7 Debt surprises, GDP growth, exchange rate, and inflation

\begin{tabular}{lcccccccc}
\hline & $\mathbf{( 1 )}$ & $\mathbf{( 2 )}$ & $\mathbf{( 3 )}$ & $\mathbf{( 4 )}$ & $\mathbf{( 5 )}$ & $\mathbf{( 6 )}$ & $\mathbf{( 7 )}$ & $\mathbf{( 8 )}$ \\
\hline \multirow{2}{*}{ GRxGT } & -0.420 & $-1.537^{* * *}$ & -0.133 & 0.042 & $-0.429^{*}$ & $-1.479 * * *$ & -0.131 & 0.042 \\
& $(0.261)$ & $(0.240)$ & $(0.291)$ & $(0.11)$ & $(0.258)$ & $(0.215)$ & $(0.288)$ & $(0.115)$ \\
\multirow{2}{*}{ GRxBT } & $-0.493^{* * *}$ & $-2.099^{* * *}$ & $-0.382^{* *}$ & -0.1950 & $-0.556^{* * *}$ & $-2.048^{* * *}$ & $-0.451^{* *}$ & -0.191 \\
& $(0.166)$ & $(0.496)$ & $(0.152)$ & $(0.528)$ & $(0.187)$ & $(0.527)$ & $(0.176)$ & $(0.479)$ \\
BT & $0.0230^{*}$ & 0.00353 & $0.0343^{*}$ & 0.026 & $0.0241^{*}$ & 0.00241 & $0.0364 * *$ & 0.026 \\
& $(0.0135)$ & $(0.0113)$ & $(0.0177)$ & $(0.93)$ & $(0.0137)$ & $(0.0110)$ & $(0.0180)$ & $(0.869)$ \\
DXR & $-0.203^{* * *}$ & -0.0212 & $-0.242^{* * *}$ & $-0.412^{* * *}$ & $-0.209 * * *$ & -0.0430 & $-0.250^{* * *}$ & $-0.412^{* * *}$ \\
& $(0.0430)$ & $(0.0524)$ & $(0.0511)$ & $(3.2819)$ & $(0.0466)$ & $(0.0548)$ & $(0.0564)$ & $(3.08)$ \\
INF & & & & & -0.0892 & $0.987 * *$ & -0.0886 & 0.011 \\
& & & & & $(0.0788)$ & $(0.376)$ & $(0.0893)$ & $(0.041)$ \\
E(GR) & $0.678^{* *}$ & 0.936 & $0.673^{* *}$ & 0.623 & $0.631^{* *}$ & 0.646 & $0.621^{* *}$ & 0.622
\end{tabular}




\begin{tabular}{lcccccccc}
\hline & $\mathbf{( 1 )}$ & $\mathbf{( 2 )}$ & $\mathbf{( 3 )}$ & $\mathbf{( 4 )}$ & $\mathbf{( 5 )}$ & $\mathbf{( 6 )}$ & $\mathbf{( 7 )}$ & $\mathbf{( 8 )}$ \\
\hline & $(0.260)$ & $(0.824)$ & $(0.276)$ & $(1.32)$ & $(0.248)$ & $(0.837)$ & $(0.262)$ & $(1.332)$ \\
N. Obs & 1,507 & 291 & 1,216 & 201 & 1,504 & 291 & 1,213 & 201 \\
N. Cy & 189 & 26 & 163 & 31 & 189 & 26 & 163 & 31 \\
Cy FE & Yes & Yes & Yes & Yes & Yes & Yes & Yes & Yes \\
Sample & All & AE & DEV\&EM & ADB & All & AE & DEV\&EM & ADB \\
\hline
\end{tabular}

Notes:

$* * * \mathrm{p}<0.01, * * \mathrm{p}<0.05, * \mathrm{p}<0.1$.

$\mathrm{ADB}=$ Asian Development Bank; AE = advanced economy; DEV\&EM = developing and emerging; GDP = gross domestic product; WEO = World Economic Outlook.

Robust standard errors in parentheses.

See Appendix Table 9A.5 for a list of economies in various groups.

Source: Author's elaborations based on different vintages of WEO data.

Table 9.8 augments the model of Table 9.7 with a set of fiscal indicators measured at time $t-1$. Columns 1-4 show that high debt-to-GDP ratios are associated with negative forecast errors (the coefficient, however, is only significant in advanced economies). When advanced economies observe growing debt ratios, they tighten policy more than anticipated. Columns 5-8 control for interest expenditure over GDP at time $t-1$ and show that this variable is negatively correlated with debt-to-GDP forecast errors, but the coefficient is only statistically significant in advanced economies. When we control interest expenditure, we find that the debt-to-GDP ratio is no longer associated with debt-to-GDP forecast errors. This finding is in line with the idea that interest expenditure over GDP is a better indicator of fiscal sustainability than the debt-to-GDP ratio.

Table 9.8 Debt surprises, GDP growth, exchange rate and inflation

\begin{tabular}{lcccccccc}
\hline & $\mathbf{( 1 )}$ & $\mathbf{( 2 )}$ & $\mathbf{( 3 )}$ & $\mathbf{( 4 )}$ & $\mathbf{( 5 )}$ & $\mathbf{( 6 )}$ & $\mathbf{( 7 )}$ & $\mathbf{( 8 )}$ \\
\hline GRxGT & -0.405 & $-1.46^{* * *}$ & -0.105 & 0.057 & -0.386 & $-1.45^{* * *}$ & -0.0634 & 0.06 \\
& $(0.260)$ & $(0.234)$ & $(0.283)$ & $(0.150)$ & $(0.270)$ & $(0.214)$ & $(0.293)$ & $(0.13)$ \\
GRxBT & $-0.66^{* * *}$ & $-1.80^{* * *}$ & $-0.55^{* * *}$ & -0.176 & $-0.67^{* * *}$ & $-1.96^{* * *}$ & $-0.58^{* * *}$ & -0.12 \\
& $(0.200)$ & $(0.493)$ & $(0.194)$ & $(0.44)$ & $(0.201)$ & $(0.472)$ & $(0.200)$ & $(0.32)$ \\
BT & $0.027^{* *}$ & 0.0024 & $0.039^{* *}$ & 0.0246 & $0.0276^{* *}$ & 0.003 & $0.042^{* *}$ & 0.02 \\
& $(0.013)$ & $(0.011)$ & $(0.017)$ & $(0.833)$ & $(0.013)$ & $(0.011)$ & $(0.018)$ & $(0.71)$ \\
DXR & $-0.21^{* * *}$ & -0.039 & $-0.25^{* * *}$ & $-0.412^{* * *}$ & $-0.22^{* * *}$ & -0.072 & $-0.25^{* * *}$ & $-0.42^{* * *}$ \\
& $(0.045)$ & $(0.053)$ & $(0.055)$ & $(0.07)$ & $(0.046)$ & $(0.051)$ & $(0.056)$ & $(3.03)$ \\
INF & -0.097 & 0.734 & -0.095 & 0.006 & -0.100 & $1.071 * *$ & -0.105 & -0.018 \\
& $(0.074)$ & $(0.430)$ & $(0.085)$ & $(0.02)$ & $(0.076)$ & $(0.460)$ & $(0.089)$ & $(0.07)$ \\
Debt/Y & $-0.060^{*}$ & $-0.060^{* *}$ & -0.053 & -0.103 & -0.043 & -0.0466 & -0.006 & -0.09 \\
& $(0.035)$ & $(0.029)$ & $(0.061)$ & $(0.68)$ & $(0.035)$ & $(0.0312)$ & $(0.063)$ & $(-.67)$ \\
INT/Y & & & & & $-0.991 * *$ & $-0.92^{* * *}$ & -1.504 & -2.75 \\
& & & & & $(0.399)$ & $(0.294)$ & $(1.145)$ & $(0.65)$ \\
E(GR) & $0.473^{* *}$ & 0.244 & $0.483^{* *}$ & 0.5105 & $0.488^{* *}$ & 0.657 & $0.492^{* *}$ & 0.39 \\
& $(0.195)$ & $(0.832)$ & $(0.214)$ & $(1.0098)$ & $(0.198)$ & $(0.767)$ & $(0.214)$ & $(0.791)$ \\
N. Obs & 1,497 & 290 & 1,207 & 201 & 1,463 & 287 & 1,176 & 197 \\
& & & & & & &
\end{tabular}




\begin{tabular}{lcccccccc}
\hline & $\mathbf{( 1 )}$ & $\mathbf{( 2 )}$ & $\mathbf{( 3 )}$ & $\mathbf{( 4 )}$ & $\mathbf{( 5 )}$ & $\mathbf{( 6 )}$ & $\mathbf{( 7 )}$ & $\mathbf{( 8 )}$ \\
\hline N. Cy & 188 & 26 & 162 & 31 & 182 & 26 & 156 & 29 \\
Cy FE & Yes & Yes & Yes & Yes & Yes & Yes & Yes & Yes \\
Sample & All & AE & DEV\&EM & ADB & All & AE & DEV\&EM & ADB \\
\hline
\end{tabular}

Notes:

$* * * \mathrm{p}<0.01, * * \mathrm{p}<0.05, * \mathrm{p}<0.1$.

$\mathrm{ADB}=$ Asian Development Bank; AE = advanced economy; DEV\&EM = developing and emerging; GDP = gross domestic product; $\mathrm{WEO}=$ World Economic Outlook.

Robust standard errors in parentheses.

See Appendix Table 9A.5 for a list of economies in various groups.

Source: Author's elaborations based on different vintages of WEO data.

Further regressions reported in Panizza (2020) show that these results do not change if one controls for lagged total government revenues over GDP or lagged tax revenues over GDP. The World Bank Control of Corruption indicator is not significantly correlated with fiscal risk. In fixed effects regression, there is a weak positive correlation between debt-to-GDP forecast errors and the open budget index (an indicator of budgetary transparency assembled by the International Budget Partnership; see Table 13 in Panizza 2020) in the full sample of developing and emerging economies. This result suggests that as economies adopt more transparent budgets, they tend to have debt outturn that is larger than expected. This is likely to be due to the fact that a more transparent budget does not allow "skeletons in the closet".

Finally, there is no evidence that a more open capital account or higher credit ratings are associated with debt-to-GDP forecast errors in the average advanced economy and developing and emerging market economies (Tables 14-16 in Panizza 2020). However, there is some evidence that when ADB regional members open their capital account they tend to face lower fiscal risk.

Panizza (2020) repeats these exercises, focusing on forecast errors for the budget balance. While most of the results are similar to those described above, there are a few notable differences.

When studying the drivers of debt-to-GDP ratio forecast errors, we found that, controlling for GDP growth, debt tends to increase more than expected during bad times in developing countries, but there is no bad-times effect in advanced economies. We also found that the correlation between GDP growth and debt-to-GDP forecast errors is stronger (in absolute value) during bad times in both advanced and developing and emerging countries. Focusing on the budget balance, we find that deficits tend to be larger than expected during bad times in advanced economies, but we find no bad-times effect in developing and emerging market countries. Similarly, we find strong asymmetric effects (with a stronger correlation between GDP growth and deficits during bad times) in advanced economies but no asymmetry in developing and emerging economies (if anything the correlation is stronger during good times). The asymmetry, however, is still present if we focus only on ADB regional members.

These findings suggest that what we observed for the debt-to-GDP ratio is mostly due to procyclical balance sheet effects in developing and emerging market countries (hence, the effect is not reflected in the budget) and to countercyclical fiscal policy in advanced economies (with the effect reflected in the budget). The importance of balance sheet effects is also reflected by the role of the exchange rate which is statistically significant for debt-to-GDP 
ratio forecast errors in developing and emerging market economies but does not have a statistically significant effect on budget balance forecast errors.

Another difference between the debt and budget balance regressions is that in the latter the lagged debt-to-GDP ratio remains statistically significant in advanced economies even after controlling for the interest rate bill. Moreover, while higher past debt ratios are associated with positive prediction errors for the budget balance (indicating a more-than-expected budget tightening after large debt realizations), we find that a higher interest rate bill is associated with negative forecast errors (suggesting larger deficits or smaller surpluses after high interest bill realizations).

\section{LEARNING FROM OUTLIERS}

To better understand the sources of large fiscal risk in ADB regional members, we first ranked all country-years by their 1-year ahead forecast error in terms of debt-to-GDP, deficit-to-GDP, and primary deficit-to-GDP and identified the top 10 and bottom 10 economies in each group.

In the list of episodes, fiscal outturns were much worse than expected in sub-Saharan Africa (57 percent of episodes), Latin America and the Caribbean (21 percent of episodes), and Middle East and North Africa (16 percent of episodes).

The list of episodes in which fiscal outturns were better than expected includes a large number of ADB regional members (48 percent of the total, the countries included in the list are ADB Pacific developing member countries), followed by countries in sub-Saharan Africa (33 percent of the total) and Latin America and the Caribbean (19 percent).

Next, we repeated the exercise by focusing only on ADB regional members and conducted a detailed analysis of IMF Article IV reports for the top- and bottom-ranked countries, to identify the causes of the forecast errors in the top 10 country-years that underperformed with respect to 1-year ahead forecasts (i.e., country-years with higher-than-expected debt and deficits) and the top 10 country-years that overperformed with respect to 1-year ahead forecasts (i.e., country-years with lower-than-expected debt and deficits).

Table $9.9 \quad$ Outliers, countries with worse-than-expected outturn

\begin{tabular}{llll}
\hline Country & Year & $\begin{array}{l}\text { Type of } \\
\text { Slippage }\end{array}$ & Description or the Main Drivers of the Forecast Error \\
\hline Azerbaijan & 2016 & $\mathrm{D}$ & $\begin{array}{l}\text { Low oil prices; banking crisis, currency depreciation with FX debt, slow growth } \\
\text { in trading partners. }\end{array}$ \\
\hline Azerbaijan & 2015 & $\mathrm{D}$ & $\begin{array}{l}\text { Low oil prices; currency depreciation with FX debt, slow growth in trading } \\
\text { partners. }\end{array}$ \\
\hline Vanuatu & 2016 & $\mathrm{D}$ & $\begin{array}{l}\text { Cyclone Pam (2015), but most of the debt increase is related to concessional debt; } \\
\text { very small economy subject to large external shocks and volatile grants. }\end{array}$ \\
\hline Kyrgyz Republic & 2015 & D & $\begin{array}{l}\text { Currency depreciation with FX debt, low gold prices, fiscal slippages linked to } \\
\text { elections. }\end{array}$ \\
\hline Lao PDR & 2014 & D & $\begin{array}{l}\text { High initial debt levels and more-than-expected debt issuance to finance } \\
\text { investment projects. }\end{array}$ \\
\hline
\end{tabular}




\begin{tabular}{|c|c|c|c|}
\hline Country & Year & $\begin{array}{l}\text { Type of } \\
\text { Slippage }\end{array}$ & Description or the Main Drivers of the Forecast Error \\
\hline India & 2015 & $\mathrm{D}$ & $\begin{array}{l}\text { High debt levels, forecast errors are partly due to higher-than-expected real } \\
\text { interest rates but no indication of other reasons for the forecast error in IMF } \\
\text { Article IV. }\end{array}$ \\
\hline Philippines & 2017 & $\mathrm{D}$ & $\begin{array}{l}\text { The increase in gross debt was mostly associated with an increase in liquid assets } \\
\text { held by the government; hence, net debt did not deviate much from what was } \\
\text { forecasted in period } t-1 \text {. }\end{array}$ \\
\hline Tajikistan & 2016 & $\begin{array}{l}\mathrm{D}, \mathrm{BB}, \\
\mathrm{PB}\end{array}$ & $\begin{array}{l}\text { Article IV reports are not available for this period. Press releases on the IMF } \\
\text { visits include the following statement: "Since late-2014, Tajikistan's economy } \\
\text { has suffered from external shocks, which affected economic confidence, reduced } \\
\text { fiscal space and external buffers, and increased vulnerabilities". }\end{array}$ \\
\hline Kazakhstan & 2015 & $\begin{array}{l}\mathrm{D}, \mathrm{BB}, \\
\mathrm{PB}\end{array}$ & $\begin{array}{l}\text { Low oil prices, lower-than-expected revenues, exchange rate depreciation in the } \\
\text { presence of FX debt. }\end{array}$ \\
\hline Tuvalu & 2016 & $\mathrm{D}$ & $\begin{array}{l}\text { Very small economy subject to large external shocks and volatile budget support } \\
\text { from Australia, New Zealand, and the United Kingdom. Note that in } 2016 \text { fiscal } \\
\text { indicators were improving, but were less than expected. }\end{array}$ \\
\hline Mongolia & 2016 & $\mathrm{BB}, \mathrm{PB}$ & $\begin{array}{l}\text { Substantial loosening of fiscal policy and increase in interest rates; anemic growth } \\
\text { linked to low commodity prices; judicial settlement with a mining company; } \\
\text { currency depreciation. }\end{array}$ \\
\hline Kazakhstan & 2016 & $\mathrm{BB}, \mathrm{PB}$ & $\begin{array}{l}\text { Lower-than-expected growth, as a consequence, the decrease of the primary } \\
\text { deficit was slower than expected. Note that in this period fiscal indicators were } \\
\text { improving, but were less than expected. }\end{array}$ \\
\hline $\begin{array}{l}\text { Papua New } \\
\text { Guinea }\end{array}$ & 2016 & $\mathrm{BB}, \mathrm{PB}$ & $\begin{array}{l}\text { Drought and decrease in price of commodity exports led to a sharp growth } \\
\text { slowdown and drop in revenues. Large recognition of contingent liabilities. }\end{array}$ \\
\hline Viet Nam & 2013 & $\mathrm{BB}, \mathrm{PB}$ & $\begin{array}{l}\text { Tax revenues fell short because of low economic growth, tariff reductions, and } \\
\text { new exemptions. Capital expenditure was higher than planned. }\end{array}$ \\
\hline Solomon Islands & 2017 & $\mathrm{BB}, \mathrm{PB}$ & $\begin{array}{l}\text { Lower tax revenues and grants, development partners pulled out of financing an } \\
\text { undersea fiber-optic cable. }\end{array}$ \\
\hline Solomon Islands & 2016 & $\mathrm{BB}$ & Unexpected decrease in grants. \\
\hline Nepal & 2018 & $\mathrm{BB}$ & Lower-than-expected grants and higher-than-expected primary expenditure. \\
\hline Tajikistan & 2017 & $\mathrm{BB}, \mathrm{PB}$ & $\begin{array}{l}\text { Article IV reports are not available for this period. Besides that mentioned in } \\
\text { 2017, press release on the IMF visits states: "There are downside risks to the fiscal } \\
\text { outlook owing to infrastructure projects". Note that in this period fiscal indicators } \\
\text { were improving, but were less than expected. }\end{array}$ \\
\hline Maldives & 2014 & PB & $\begin{array}{l}\text { Large increase of the primary deficit to higher expenditures for subsidies, public } \\
\text { sector wages, and social welfare. }\end{array}$ \\
\hline Maldives & 2016 & PB & $\begin{array}{l}\text { Lower-than-expected revenues and large arrears clearance despite unchanged } \\
\text { current spending. }\end{array}$ \\
\hline
\end{tabular}

Note: $\mathrm{BB}=$ budget balance; $\mathrm{D}=$ debt-to-GDP; FX = foreign currency; IMF = International Monetary Fund; Lao $\mathrm{PDR}=$ Lao People's Democratic Republic; $\mathrm{PB}=$ primary balance.

Source: Author's classification based on analysis of IMF Article IV reports.

Tables 9.9 and 9.10 summarize the outcome of this exercise. Although the maximum number of underperformers is 30 (10 country-years and three indicators), countries that in a given year underperform in one fiscal indicator often underperform in other indicators. Hence, the list 
of underperformers (Table 9.9) contains only 20 observations. The same applies to the list of overperformers (Table 9.10).

\section{Table $9.10 \quad$ Outliers, countries with better-than-expected outturns}

\begin{tabular}{|c|c|c|c|}
\hline Country & Year & $\begin{array}{l}\text { Type of } \\
\text { Overperformance }\end{array}$ & Description or the Main Drivers of the Forecast Error \\
\hline Bhutan & 2015 & $\mathrm{D}$ & $\begin{array}{l}\text { Lower-than-expected public investment in hydropower investment } \\
\text { projects. Debt was still increasing but it was less than expected. }\end{array}$ \\
\hline Azerbaijan & 2018 & $\mathrm{D}$ & Increase in oil price and higher-than-expected growth. \\
\hline Viet Nam & 2018 & $\mathrm{D}$ & High growth, tight fiscal policy. \\
\hline Azerbaijan & 2017 & $\mathrm{D}$ & $\begin{array}{l}\text { Debt was still growing but at a slower pace than expected because of } \\
\text { lower contingent liabilities realization than expected. }\end{array}$ \\
\hline $\begin{array}{l}\text { Kyrgyz } \\
\text { Republic }\end{array}$ & 2017 & $\mathrm{D}$ & $\begin{array}{l}\text { Currency appreciation and debt relief from the Russian Federation; } \\
\text { debt was still increasing but it was less than expected. }\end{array}$ \\
\hline Myanmar & 2014 & $\mathrm{D}$ & $\begin{array}{l}\text { Currency appreciation against a basket of currencies in which } \\
\text { Myanmar's external debt is denominated. }\end{array}$ \\
\hline Cambodia & 2018 & $\mathrm{D}$ & Higher-than-expected growth and lower-than-expected fiscal deficit. \\
\hline Kiribati & 2018 & $\mathrm{D}$ & $\begin{array}{l}\text { Strong fishing revenues and strong economic performance; very small } \\
\text { economy subject to large external shocks and volatile grants. }\end{array}$ \\
\hline Tuvalu & 2018 & $\mathrm{D}, \mathrm{BB}, \mathrm{PB}$ & $\begin{array}{l}\text { Very small economy subject to large external shocks and volatile } \\
\text { budget support from Australia, New Zealand, and the United } \\
\text { Kingdom. }\end{array}$ \\
\hline Kazakhstan & 2011 & $\mathrm{D}$ & $\begin{array}{l}\text { High GDP growth linked to high commodity prices, small } \\
\text { appreciation of the currency. }\end{array}$ \\
\hline Tuvalu & 2013 & $\mathrm{BB}, \mathrm{PB}$ & $\begin{array}{l}\text { Very small economy subject to large external shocks and volatile } \\
\text { budget support from Australia, New Zealand, and the United } \\
\text { Kingdom. }\end{array}$ \\
\hline Tuvalu & 2015 & $\mathrm{BB}$ & $\begin{array}{l}\text { Very small economy subject to large external shocks and volatile } \\
\text { budget support from Australia, New Zealand, and the United } \\
\text { Kingdom. }\end{array}$ \\
\hline Kiribati & 2017 & $\mathrm{BB}, \mathrm{PB}$ & $\begin{array}{l}\text { Fiscal indicators were deteriorating but were less than expected } \\
\text { because of stronger-than-expected economic growth and fishing } \\
\text { revenues. Very small economy subject to large external shocks and } \\
\text { volatile grants. Grants did not decrease as much as expected. }\end{array}$ \\
\hline Tuvalu & 2017 & $\mathrm{BB}, \mathrm{PB}$ & $\begin{array}{l}\text { Very small economy subject to large external shocks and volatile } \\
\text { budget support from Australia, New Zealand, and the United } \\
\text { Kingdom. }\end{array}$ \\
\hline Kiribati & 2016 & $\mathrm{BB}, \mathrm{PB}$ & $\begin{array}{l}\text { Fishing revenues exceeded the budget projection by } 25 \text { percent } \\
\text { leading to an unexpected budget surplus. Very small economy subject } \\
\text { to large external shocks and volatile grants. }\end{array}$ \\
\hline $\begin{array}{l}\text { Federated States } \\
\text { of Micronesia }\end{array}$ & 2018 & BB & $\begin{array}{l}\text { Higher-than-expected economic growth, fishing license fees, } \\
\text { corporate tax payment from investment companies domiciled in the } \\
\text { islands, and foreign grants. Very small economy subject to large } \\
\text { external shocks and volatile grants. }\end{array}$ \\
\hline
\end{tabular}




\begin{tabular}{llll}
\hline Country & Year & $\begin{array}{l}\text { Type of } \\
\text { Overperformance }\end{array}$ & Description or the Main Drivers of the Forecast Error \\
\hline Vanuatu & 2017 & BB & $\begin{array}{l}\text { Very small economy subject to large external shocks and volatile } \\
\text { grants. The deficit was lower than expected because of a pickup } \\
\text { in GDP growth and lower-than-expected public investment for } \\
\text { reconstruction after Cyclone Pam. }\end{array}$ \\
\hline Vanuatu & 2018 & BB, PB & $\begin{array}{l}\text { Very small economy subject to large external shocks and volatile } \\
\text { grants. The deficit was lower than expected because of a pickup } \\
\text { in GDP growth and lower-than-expected public investment for } \\
\text { reconstruction after Cyclone Pam. }\end{array}$ \\
\hline Maldives & 2017 & BB, PB & $\begin{array}{l}\text { Higher-than-expected growth and lower-than-expected primary } \\
\text { expenditure (with revenues remaining constant). }\end{array}$ \\
\hline Maldives & 2013 & PB & $\begin{array}{l}\text { A rebound in growth improved the fiscal situation even though the } \\
\text { fiscal deficit remains high. }\end{array}$ \\
\hline
\end{tabular}

Note $: \mathrm{BB}=$ budget balance; $\mathrm{D}=$ debt-to-GDP; GDP = gross domestic product; IMF = International Monetary Fund; Lao PDR = Lao People's Democratic Republic; $\mathrm{PB}=$ primary balance.

Source: Author's classification based on analysis of IMF Article IV reports.

The first two columns of Tables 9.9 and 9.10 report the countries and years with large forecast errors, the third column describes the fiscal indicators (D for debt-to-GDP, BB for budget balance, and $\mathrm{PB}$ for primary balance) with large forecast errors in a given country-year, and the last column provides a short description of the drivers of the forecast errors based on the analysis of Article IV reports. The tables order country-years on the basis of the size of the debt forecast errors, followed by a ranking first based on the size of the budget deficit forecast error, and then the primary deficit forecast error. ${ }^{15}$

While Tables 9.9 and 9.10 could include up to 40 countries (20 countries each), the tables include only 20 countries because a number of countries appear multiple times in each of the two tables, and seven countries (Azerbaijan, Kazakhstan, the Kyrgyz Republic, Maldives, Tuvalu, Vanuatu, and Viet Nam) appear in both lists. The data suggest that these countries have fiscal forecasts that are particularly noisy, with large overpredictions and underpredictions of fiscal outturns.

Moreover, Azerbaijan, Kazakhstan, Maldives, Solomon Islands, and Tajikistan appear twice in Table 9.9; Kiribati, Tuvalu, and Vanuatu appear twice in Table 9.10; and Azerbaijan and Maldives appear twice in Table 9.10. These 10 countries account for 75 percent of the observations included in Tables 9.9 and 9.10. Azerbaijan, Maldives, and Tuvalu alone account for 33 percent of observations.

Looking at the characteristics of the countries in the two lists, we find that in the list of underperformers eight entries are commodity producers, six entries are small island states, and only three entries are countries with a more diversified economy and a substantial manufacturing sector. Focusing on the list of overperformers, we find 13 entries for ADB Pacific developing member countries and four entries for commodity exporters.

Besides being grouped in a small number of countries, the observations of Tables 9.9 and 9.10 are also grouped in a small number of years. In Table 9.9, 65 percent of observations are for two years in which commodity prices were decreasing (nine observations for 2016 and four for 2015) and in Table 9.10, 65 percent of observations are for two years in which commodity process were increasing (seven observations for 2018 and 6 for 2017). 
Tables 9.9 and 9.10 also show that for commodity exporters fiscal risk is mostly driven by volatility in commodity prices. In small island states, fiscal risk is driven by the volatile macro environment caused by the small size of the economy and by volatility in grants, tourism and fishing revenues. Currency depreciations in the presence of foreign currency debt are an important source of fiscal risk with respect to the debt indicator (40 percent of the debt surprises listed in Table 9.9 are associated with currency depreciations).

\section{CONCLUSIONS}

Forecasts always have a margin of error, but unbiased forecasts should be correct on average (that is the error should have a mean of zero). However, fiscal plans often go astray in a specific direction as larger-than-expected debt and deficits are much more likely than smaller-than-expected debt and deficits. It is probably for this reason that all the IMF documents reviewed for this chapter include the sentence, "Risks to the outlook are tilted to the downside".

The concept of fiscal risk reflects the presence of large or systematic deviations of fiscal outcomes from their expected values. This chapter describes and quantifies fiscal risk focusing on public debt-to-GDP ratio and fiscal deficit (both overall and primary) to GDP ratio. The chapter finds that fiscal risk is substantial, especially in developing and emerging economies. In advanced economies about 40 percent of the variance of fiscal risks is explained by GDP growth shocks; in developing and emerging countries growth shocks explain less than 10 percent of the variance of fiscal risk. Focusing on the debt-to-GDP ratio, the chapter finds that it is difficult to explain forecast errors by simply focusing on forecast errors in the standard debt-dynamic variables equation. In both advanced and emerging economies, more than 50 percent of the forecast error is associated with a non-easily observable residual entity. Campos et al. (2006) call this "the unexplained part of debt".

The chapter also finds that fiscal risk is especially high in bad times, even when there are no forecast errors for GDP growth. This finding is often due to fiscal slippages in advanced economies and the presence of negative balance sheet effects in developing and emerging market economies.

The average value for ADB regional members differs from those of developing countries as a whole. First, if we measure fiscal risk by the mean difference of outturn versus forecasts or by the skewedness of this difference, we find that forecasts are less optimistic in the average $\mathrm{ADB}$ regional member than in other developing and emerging economies. Second, the standard deviation of the forecast errors for the debt-to-GDP ratio in ADB regional members is similar to that for other developing and emerging market economies, but the standard deviation of forecast errors for the budget deficit is much higher in ADB regional members. Third, the analysis of outliers shows that ADB regional members are underrepresented among outliers for which fiscal outturns were worse than expected and overrepresented among outliers for which outturns were better than expected. And among these outliers, all ADB regional members are Pacific developing member countries.

These findings have important policy implications. When forecast errors are biased in one specific direction, the main policy priority should be to eliminate the source of this bias, especially if this bias leads to overly optimistic forecasts (see Beaudry and Willems forthcoming). 
The results of this chapter suggest that this is less of a problem for the typical ADB regional member than for the typical developing and emerging country.

Forecast errors that are large but with no obvious bias could be driven by poor forecasting capacity or by the fact that an economy is subject to very large shocks. Small economies are likely to be subject to both of these problems as they are likely to have insufficient resources to invest in data collection and forecasting capacity which mostly involve fixed costs (the forecasts used in this chapter are by IMF economists but based on national data) and also tend to be less diversified and, hence, more volatile than larger economies.

Investing in better forecasting capacity can have high returns as there is evidence that better data quality and transparency is associated with lower spreads (Choi and Hashimoto 2017). For countries that are subject to large external shocks (both weather-related and linked to commodity price fluctuations) there is little that can be done in terms of baseline forecasts (countries can, however, incorporate uncertainty with a fan-chart approach that allows for tail events; see IMF 2016). Countries subject to large exogenous shocks can, however, increase resilience by issuing contingent debt instruments as discussed in Chapter 15 on fiscal insurance in this volume.

\section{NOTES}

1. The views expressed therein are those of the authors and do not necessarily reflect the views and policies of ADB, its Board of Governors or the governments they represent. The author thanks Benno Ferrarini, Marcelo Giugale, Juan Pradelli, Andrea Presbitero, Hernán Seoane, and Reza Vaez-Zadeh for commissioning this chapter and providing helpful feedback, and Xi Kang for outstanding research assistance. The usual caveats apply. This chapter only reports a subset of the results included in the original study. For a full set of results, see Panizza (2020).

2. The government budget balance is defined as total government revenues minus total government expenditures. The primary budget balance is defined as the budget balance net of interest revenues and expenditure.

3. While it would have been interesting to also examine risks associated with different components of the government balance (government revenues, public sector wage bill, etc.), lack of systematic forecasts for these variables prevented such an exercise.

4. Evidence however shows that the optimism on these forecasts may depend on the characteristics of the economist in charge of a given country (Beaudry and Willems forthcoming).

5. Cebotari et al. (2009) use a panel of 27 advanced economies for 1995-2007 and 131 developing and emerging economies for 2002-2007.

6. For instance, we compare the outturn for the debt-to-GDP ratio in 2018 (using 2020 WEO data) with the WEO forecasts of Fall 2017 (for $t-1$ forecasts) and Fall 2016 (for $t-2$ forecasts). For 2019 and 2020, we measure the outturn using data for the June 2020 WEO and compare them with October 2017 and October 2018 for 2019 and October 2018 and October 2019 for 2020.

7. Developing economies and regions refer to the World Bank classification (see Appendix Table 9A.5). Developing Asia refers to developing economies in Asia, mostly South Asia and East Asia and Pacific (EAP) in the World Bank classification and ADB regional members.

8. The median country has an outturn which is lower than forecasted at $t-1$ and $t-2$, and the country at the 90th percentile of the distribution has a difference between outturn and forecast which is 3 percentage points of GDP larger (in absolute value) than the country at the 10th percentile of the distribution. The standard deviation is nearly 30 times the average value of the forecast error.

9. The country at the 90th percentile of the distribution has a difference between outturn and forecast which is 11 percent of GDP larger, in absolute value, than the country at the 10th percentile of the distribution.

10. The observation at the 10th percentile has an outturn which is 3.4 percent of GDP below expectations (5.2 percent of GDP for 2-year ahead forecasts) and the observations at the 90th percentile 
have an outturn which is about 2.5 percent of GDP above expectations for both 1-year and 2-year forecasts.

11. The bottom panel of Table 9.2, which focuses on forecast errors with respect to time $t-2$, reports results that are similar to those of the top panel (the only difference is that for 2-year forecast errors there is a stronger correlation between advanced economies' GDP growth forecast errors and debt-to-GDP forecast errors).

12. As suggested by its name, the stock-flow reconciliation is a residual entity that reconciles the deficit, which is a "flow" variable, with the evolution of debt, which is a "stock" variable. Campos et al. (2006) call the stock-flow reconciliation "the unexplained part of public debt".

13. We obtain similar results if, instead of focusing on the overall budget balance, we study the correlation between forecast errors in GDP growth and forecast errors in the primary balance. In this case, however, we find that the point estimates for ADB regional members are very close to those for advanced economies (the share of variance remains lower, however).

14. One possible explanation for this result is that fiscal consolidations during good times are easier to forecast than sudden deteriorations.

15. Note that the country-years included in the list of Table 9.9 did not necessarily face deteriorating fiscal conditions. In about 30 percent of cases, fiscal indicators were improving, but less than expected. The same applies to the list in Table 9.10, which includes four country-years with deteriorating fiscal indicators, but where the deterioration of these indicators was smaller than expected.

\section{REFERENCES}

Beaudry, P. and T. Willems. Forthcoming. On the Macroeconomic Consequences of Over-Optimism. American Economic Journal: Macroeconomics.

Bova, E., M. Ruiz-Arranz, F. Toscani and E. Ture. 2019. The Impact of Contingent Liability Realizations on Public Finances. International Tax and Public Finance. 26, pp. 381-417.

Brixi, H. and A. Schick. 2002. Government at Risk: Contingent Liabilities and Fiscal Risk. New York: Oxford University Press.

Budina, N. and M. Petrie. 2013. Managing and Controlling Fiscal Risk. In C. Cangiano and M. Lazare (eds), Public Financial Management and Its Emerging Architecture. International Monetary Fund (IMF), Washington DC.

Campos, C., D. Jaimovich and U. Panizza. 2006. The Unexplained Part of Public Debt. Emerging Markets Review. 7, pp. 228-43.

Cebotari, A., J. Davis, L. Lusinyan, A. Mati, P. Mauro, M. Petrie and R. Velloso. 2009. Fiscal Risks, Sources, Disclosure, and Management. Washington, DC: IMF.

Celasun, O., X. Debrun and J. Ostry. 2006. Primary Surplus Behavior and Risks to Fiscal Sustainability in Emerging Market Countries: A Fan Chart Approach. IMF Staff Papers. 53, pp. 401-425.

Choi, S. and Y. Hashimoto. 2017. The Effects of Data Transparency Policy Reforms on Emerging Market Sovereign Bond Spreads. IMF Working Paper. No. 17/74. Washington, DC: IMF.

Eichengreen, B., R. Hausmann and U. Panizza. 2005. The Pain of Original Sin. In B. Eichengreen and R. Hausmann (eds), Other People's Money. Chicago, IL: University of Chicago Press.

Hausmann, R. and U. Panizza. 2011. Redemption or Abstinence? Original Sin, Currency Mismatches and Counter Cyclical Policies in the New Millennium. Journal of Globalization and Development. 2(1), pp. 1-35.

Independent Evaluation Office. 2014. IMF Forecasts: Process, Quality, and Country Perspectives. Washington, DC: IMF.

International Monetary Fund (IMF). 2016. Analyzing and Managing Fiscal Risk: Best Practices. Washington, DC: IMF.

Jaramillo, L., C. Mulas-Granados and E. Kimani. 2016. The Blind Side of Public Debt Spikes. IMF Working Paper. No. 16/202. Washington, DC: IMF.

Panizza, U. 2020. Fiscal Risk and its Drivers: An Empirical Analysis. IHEID Working Papers. 17-2020. Economics Section, The Graduate Institute of International Studies. 
Panizza, U. and F. Taddei. 2020. Local Currency Denominated Sovereign Loans - A Portfolio Approach to Tackle Moral Hazard and Provide Insurance. IHEID Working Papers. 09-2020. Economics Section, The Graduate Institute of International Studies.

Schick, A. 1998. A Contemporary Approach to Public Expenditure Management. Washington, DC: The World Bank.

Weber, A. 2012. Stock-Flow Adjustments and Fiscal Transparency: A Cross-Country Comparison. IMF Working Paper. No. 12/39. Washington, DC: IMF. 


\section{APPENDIX 9.1}

Table 9A.1 Debt-to-GDP ratio, outturn versus forecasts, ADB regional members (\%)

\begin{tabular}{|c|c|c|c|c|c|c|c|c|}
\hline Group & Mean & Median & SD & P10 & $\mathbf{P} 25$ & P75 & P90 & Skew \\
\hline \multicolumn{9}{|c|}{ Outturn $-E_{t-1}$ (all available years) } \\
\hline All & -0.23 & -0.02 & 9.67 & -8.04 & -3.33 & 3.46 & 7.78 & -0.81 \\
\hline CWA & 0.08 & 0.54 & 8.17 & -8.28 & -5.25 & 2.98 & 7.78 & 0.24 \\
\hline SA & -2.12 & 0.74 & 15.39 & -23.31 & -2.48 & 4.74 & 10.00 & -1.35 \\
\hline SEA & -0.36 & 0.06 & 5.57 & -6.34 & -3.78 & 3.33 & 6.70 & -0.47 \\
\hline EA & 6.40 & 3.17 & 9.70 & -3.85 & -1.80 & 15.20 & 19.85 & 0.33 \\
\hline PA & 0.01 & -1.00 & 8.75 & -8.82 & -3.25 & 2.63 & 7.27 & 1.84 \\
\hline \multicolumn{9}{|c|}{ Outturn $-E_{t-2}$ (all available years) } \\
\hline All & -0.03 & 0.46 & 11.95 & -10.74 & -4.56 & 5.38 & 11.10 & -1.43 \\
\hline CWA & 1.24 & 1.84 & 10.23 & -11.84 & -3.55 & 7.65 & 12.95 & -0.03 \\
\hline SA & -3.59 & 0.69 & 19.69 & -36.81 & -7.03 & 5.03 & 12.63 & -1.51 \\
\hline SEA & -0.25 & 0.47 & 6.70 & -8.91 & -4.60 & 5.36 & 7.88 & -0.66 \\
\hline EA & 10.72 & 13.16 & 11.71 & -5.60 & -0.11 & 21.37 & 22.56 & -0.22 \\
\hline PA & -0.08 & -1.80 & 9.33 & -8.83 & -3.92 & 1.93 & 14.63 & 1.23 \\
\hline
\end{tabular}

Notes:

$\mathrm{ADB}=$ Asian Development Bank; CWA = Central and West Asia; EA = East Asia; GDP = gross domestic product; $\mathrm{PA}=$ Pacific; $\mathrm{SA}=$ South Asia; SEA = Southeast Asia; WEO = World Economic Outlook.

For a list of ADB regional members, see ADB. Regional Members: https://www.adb.org/about/members.

Source: Author's calculations based on different vintages of WEO.

Table 9A.2 Budget balance-to-GDP ratio, outturn versus forecasts, ADB regional members (\%)

\begin{tabular}{|c|c|c|c|c|c|c|c|c|}
\hline Group & Mean & Median & SD & P10 & P25 & P75 & P90 & Skew \\
\hline \multicolumn{9}{|c|}{ Outturn $-E_{t-1}$ (all available years) } \\
\hline All & 0.99 & 0.00 & 7.60 & -4.57 & -2.01 & 1.93 & 5.57 & 3.17 \\
\hline CWA & -0.70 & -0.23 & 4.05 & -5.28 & -3.06 & 1.70 & 3.39 & -0.06 \\
\hline SA & -0.09 & -0.03 & 4.79 & -4.07 & -1.87 & 1.45 & 4.55 & -0.27 \\
\hline SEA & 0.17 & 0.24 & 2.18 & -2.48 & -1.06 & 1.48 & 2.58 & -0.17 \\
\hline EA & -0.91 & -0.78 & 4.65 & -5.85 & -3.74 & 0.61 & 2.00 & 0.64 \\
\hline PA & 4.34 & 1.41 & 12.53 & -6.02 & -2.08 & 5.07 & 21.97 & 1.89 \\
\hline \multicolumn{9}{|c|}{ Outturn $-E_{t-2}$ (all available years) } \\
\hline All & 0.61 & -0.17 & 8.58 & -5.30 & -2.40 & 1.97 & 5.78 & 1.62 \\
\hline CWA & -1.27 & -0.89 & 4.58 & -6.80 & -3.73 & 1.21 & 4.98 & -0.80 \\
\hline SA & -0.57 & -0.41 & 5.03 & -5.93 & -3.10 & 1.46 & 5.10 & -0.22 \\
\hline SEA & 0.15 & 0.01 & 2.28 & -2.91 & -0.96 & 1.22 & 3.25 & 0.16 \\
\hline EA & -1.25 & -1.02 & 5.43 & -9.51 & -3.22 & 0.30 & 5.00 & 0.61 \\
\hline PA & 3.87 & 0.61 & 14.48 & -5.08 & -2.11 & 4.63 & 23.82 & 0.66 \\
\hline
\end{tabular}




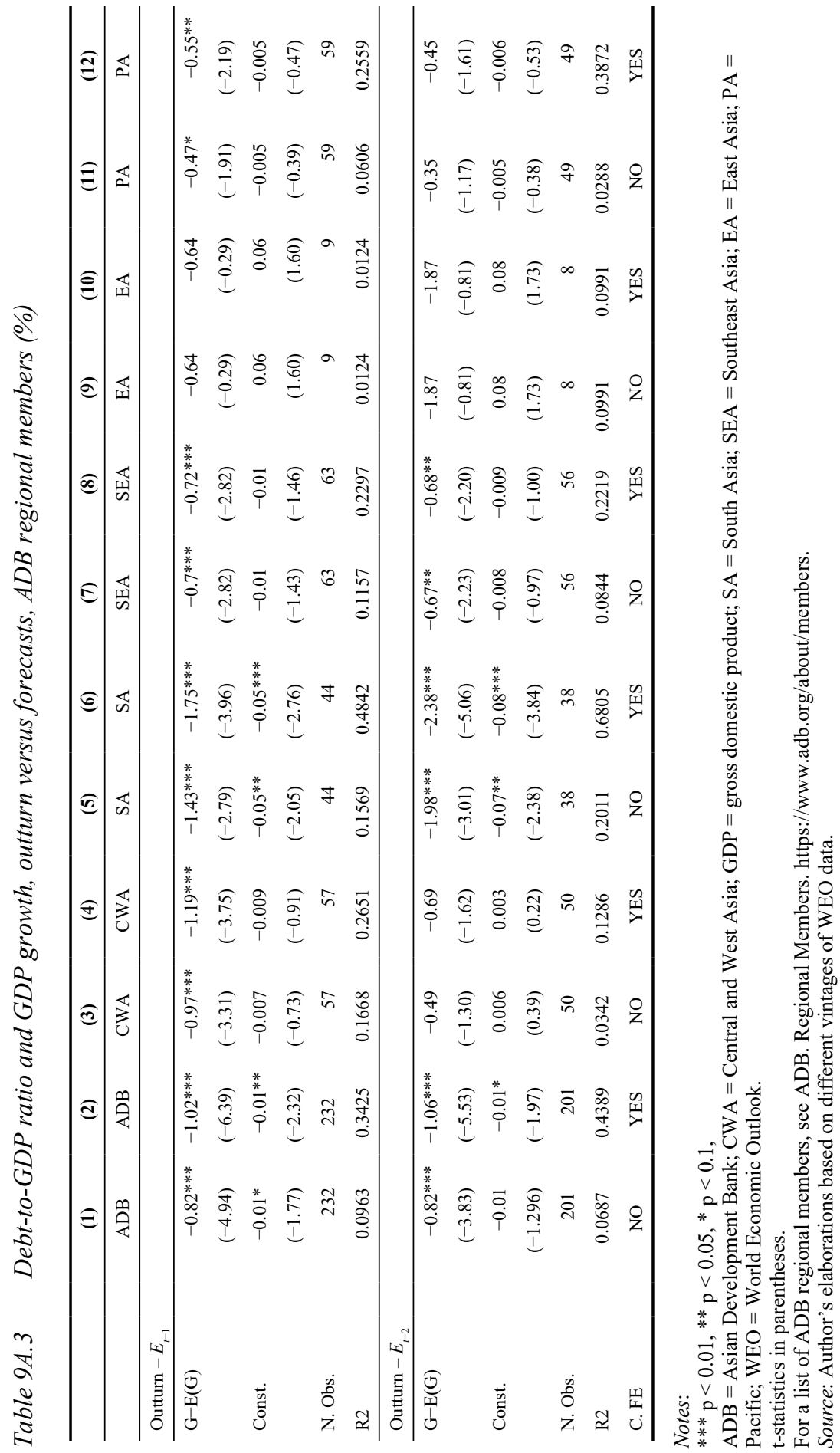


Table 9A.4 Debt-to-GDP ratio and GDP growth, decomposition of outturn versus forecasts, $A D B$ regional members (\%)

\begin{tabular}{lrrrrr}
\hline & $\boldsymbol{p b}$ & $\boldsymbol{i n t}$ & $\boldsymbol{i n f}$ & $\boldsymbol{g r}$ & $\boldsymbol{\varepsilon}$ \\
\hline $\mathrm{Outturn}-E_{t-1}$ & & & & & \\
\hline $\mathrm{ADB} \mu$ & 23.25 & 2.71 & 3.35 & 7.12 & 59.81 \\
$\mathrm{ADB} \sigma$ & 126.54 & 12.65 & 30.55 & 23.70 & 137.61 \\
$\mathrm{CWA} \mu$ & 60.34 & 2.34 & 2.27 & 7.01 & 23.83 \\
$\mathrm{CWA} \sigma$ & 113.01 & 8.69 & 27.08 & 21.95 & 143.17 \\
$\mathrm{SA} \mu$ & 5.71 & 6.86 & 3.41 & 17.12 & 72.85 \\
$\mathrm{SA} \sigma$ & 17.58 & 29.60 & 34.70 & 135.75 \\
$\mathrm{SEA} \mu$ & 2.11 & 10.45 & 2.48 & 69.77 \\
$\mathrm{SEA} \sigma$ & 16.06 & 10.73 & 35.35 & 15.73 & 82.84 \\
$\mathrm{EA} \mu$ & 83.97 & -4.38 & -8.64 & 2.00 & 208.45 \\
$\mathrm{EA} \sigma$ & -35.51 & 9.37 & 19.22 & 5.85 & 145.09 \\
$\mathrm{PA} \mu$ & 154.95 & 0.84 & -1.34 & 5.40 & 50.25 \\
$\mathrm{PA} \sigma$ & 20.24 & 12.71 & 29.93 & 23.07 & 189.09 \\
\hline
\end{tabular}

Notes:

$\mu=$ mean; $\sigma=$ standard deviation; $\mathrm{ADB}=$ Asian Development Bank; CWA = Central and West Asia; GDP $=$ gross domestic product; $\mathrm{SA}=$ South Asia; $\mathrm{SEA}=$ Southeast Asia; EA = East Asia; PA = Pacific; WEO = World Economic Outlook.

For a list of ADB regional members, see ADB. Regional Members; https://www.adb.org/about/members.

Source: Author's calculations based on different vintages of WEO data. 
Table 9A.5a World Bank classification of economies

\begin{tabular}{|c|c|c|c|c|}
\hline \multirow{2}{*}{$\begin{array}{l}\text { Advanced } \\
\text { Economies }\end{array}$} & \multicolumn{2}{|l|}{ Low Income } & \multicolumn{2}{|l|}{ Middle Income } \\
\hline & Afghanistan & Liberia & Albania & Kosovo \\
\hline Austria & Bangladesh & Madagascar & Algeria & Lebanon \\
\hline Belgium & Benin & Malawi & Angola & Libya \\
\hline Canada & Bhutan & Mali & Argentina & Malaysia \\
\hline Cyprus & Burkina Faso & Mauritania & Armenia & Maldives \\
\hline Denmark & Burundi & $\begin{array}{l}\text { Federated States of } \\
\text { Micronesia }\end{array}$ & Azerbaijan & Marshall Islands \\
\hline Finland & Cabo Verde & Moldova & Belarus & Mauritius \\
\hline France & Cambodia & Mongolia & Belize & Mexico \\
\hline Germany & Cameroon & Mozambique & Bolivia & Montenegro, Rep. of \\
\hline Greece & $\begin{array}{l}\text { Central African } \\
\text { Republic }\end{array}$ & Myanmar & Bosnia and Herzegovina & Morocco \\
\hline Iceland & Chad & Nepal & Botswana & Namibia \\
\hline Ireland & Comoros & Nicaragua & Brazil & Nauru \\
\hline Israel & Congo, Dem Rep & Niger & Bulgaria & Nigeria \\
\hline Italy & Congo, Republic of & Papua New Guinea & $\begin{array}{l}\text { People's Republic of } \\
\text { China }\end{array}$ & North Macedonia \\
\hline Japan & Cote d'Ivoire & Rwanda & Colombia & Pakistan \\
\hline Korea, Republic of & Djibouti & Sao Tome and Principe & Costa Rica & Paraguay \\
\hline Luxembourg & Eritrea & Sierra Leone & Dominica & Peru \\
\hline Malta & Eswatini & Solomon Islands & Dominican Republic & Philippines \\
\hline Netherlands & Ethiopia & Somalia & Ecuador & Romania \\
\hline New Zealand & Gambia, The & South Sudan & Egypt & Russian Federation \\
\hline Norway & Ghana & Sudan & El Salvador & Samoa \\
\hline Portugal & Guinea & Syria & Equatorial Guinea & Senegal \\
\hline Singapore & Guinea-Bissau & Tajikistan & Fiji & Serbia \\
\hline Spain & Haiti & Tanzania & Gabon & South Africa \\
\hline Sweden & Kiribati & Timor-Leste & Georgia & Sri Lanka \\
\hline Switzerland & Kyrgyz Republic & Togo & Guatemala & Suriname \\
\hline United Kingdom & $\begin{array}{l}\text { Lao People's } \\
\text { Democratic } \\
\text { Republic }\end{array}$ & Uganda & Honduras & Thailand \\
\hline \multirow[t]{9}{*}{ United States } & Lesotho & Vanuatu & India & Tonga \\
\hline & & West Bank and Gaza & Indonesia & Tunisia \\
\hline & & Yemen & Iran & Turkey \\
\hline & & Zambia & Iraq & Turkmenistan \\
\hline & & Zimbabwe & Jamaica & Tuvalu \\
\hline & & & Jordan & Ukraine \\
\hline & & & Kazakhstan & Uzbekistan \\
\hline & & & Kenya & Venezuela \\
\hline & & & & Viet Nam \\
\hline
\end{tabular}


Table 9A.5b World Bank classification of economies

\begin{tabular}{|c|c|c|}
\hline East Asia and Pacific & Eastern Europe and Central Asia & Latin America and the Caribbean \\
\hline Brunei Darussalam & Albania & Antigua and Barbuda \\
\hline Cambodia & Armenia & Argentina \\
\hline People's Republic of China & Azerbaijan & Aruba \\
\hline Fiji & Belarus & Bahamas, The \\
\hline Indonesia & Bosnia and Herzegovina & Barbados \\
\hline Kiribati & Bulgaria & Belize \\
\hline Lao People's Democratic Republic & Croatia & Bolivia \\
\hline Malaysia & Czech Republic & Brazil \\
\hline Marshall Islands & Estonia & Chile \\
\hline Federated States of Micronesia & Georgia & Colombia \\
\hline Mongolia & Hungary & Costa Rica \\
\hline Myanmar & Kazakhstan & Dominica \\
\hline Nauru & Kosovo & Dominican Republic \\
\hline Palau & Kyrgyz Republic & Ecuador \\
\hline Papua New Guinea & Latvia & El Salvador \\
\hline Philippines & Lithuania & Grenada \\
\hline Samoa & Moldova & Guatemala \\
\hline Solomon Islands & Montenegro, Rep. of & Haiti \\
\hline Thailand & North Macedonia & Honduras \\
\hline Timor-Leste & Poland & Jamaica \\
\hline Tonga & Romania & Mexico \\
\hline Tuvalu & Russian Federation & Nicaragua \\
\hline Vanuatu & Serbia & Panama \\
\hline \multirow[t]{7}{*}{ Viet Nam } & Slovak Republic & Paraguay \\
\hline & Slovenia & Peru \\
\hline & Tajikistan & St. Kitts and Nevis \\
\hline & Turkey & Suriname \\
\hline & Turkmenistan & Trinidad and Tobago \\
\hline & Ukraine & Uruguay \\
\hline & Uzbekistan & Venezuela \\
\hline
\end{tabular}


Table 9A.5c World Bank classification of economies

\begin{tabular}{|c|c|c|c|}
\hline Middle East and North & South Asia & Sub-Saharan Africa & \\
\hline Algeria & Afghanistan & Angola & Liberia \\
\hline Bahrain & Bangladesh & Benin & Madagascar \\
\hline Djibouti & Bhutan & Botswana & Malawi \\
\hline Egypt & India & Burkina Faso & Mali \\
\hline Iran & Maldives & Burundi & Mauritania \\
\hline Iraq & Nepal & Cabo Verde & Mauritius \\
\hline Jordan & Pakistan & Cameroon & Mozambique \\
\hline Kuwait & Sri Lanka & Central African Republic & Namibia \\
\hline Lebanon & & Chad & Niger \\
\hline Libya & & Comoros & Nigeria \\
\hline Malta & & Congo, Dem Rep & Rwanda \\
\hline Morocco & & Congo, Republic of & Senegal \\
\hline Oman & & Cote d'Ivoire & Seychelles \\
\hline Qatar & & Equatorial Guinea & Sierra Leone \\
\hline Saudi Arabia & & Eritrea & Somalia \\
\hline Syria & & Eswatini & South Africa \\
\hline Tunisia & & Ethiopia & South Sudan \\
\hline United Arab Emirates & & Gabon & Sudan \\
\hline West Bank and Gaza & & Gambia, The & Sao Tome and Principe \\
\hline \multirow[t]{5}{*}{ Yemen } & & Ghana & Tanzania \\
\hline & & Guinea & Togo \\
\hline & & Guinea-Bissau & Uganda \\
\hline & & Kenya & Zambia \\
\hline & & Lesotho & Zimbabwe \\
\hline
\end{tabular}

